$\underline{\text { Review Article }}$

\title{
A REVIEW ON SCOPES, METHODS AND RATIONALE OF INTEGRATIVE APPROACH IN SIDDHA MEDICINE WITH BIOMEDICINE
}

\author{
S. RAJALAKSHMI ${ }^{*}$, P. SATHIYARAJESWARAN ${ }^{2}$, K. SAMRAJ ${ }^{3}$, K. KANAGAVALLI $^{4}$
}

1,3Siddha Clinical Research Unit (SCRU), Tirupati, Andhra Pradesh, India, ${ }^{2}$ Director, Siddha Central Research Institute (SCRI), Chennai, Tamilnadu, India, ${ }^{4}$ Director General, Central Council for Research in Siddha (CCRS), Chennai, Tamilnadu, India

Email: dr.rajibsms23@gmail.com

Received: 29 Jan 2020, Revised and Accepted: 06 Mar 2020

\begin{abstract}
In India, according to WHO 2018 statistics, there were 63\% of death occurred due to Non-communicable diseases (NCDs), in which Cardiovascular diseases were leading cause of death $27 \%$, followed by Cancer $9 \%$, Chronic respiratory disease $11 \%$, Diabetes $3 \%$ and other NCDs $13 \%$. This indicates that NCDs needs to become a priority in controlling and preventing. Therefore, the only effective intervention may be at controlling and preventing NCDs disease is Integrative Medicine. Integrative Medicine is a medical practice synthesizing Traditional medicine and Biomedicine preventive measures and treatment interventions. Autonomy of patients may end in no benefit out of their ignorance to select between the treatment options available in a country like India where Seven Recognized medical systems are available as a platter. Siddha system of medicine is one of the traditional medicines of India, practiced in the southern part of the country. This study aims at providing Health care system under one roof, in order to save public money, time and health as an existing model as co-location in Tamil Nadu. This can be achieved through assessing feasible areas of integration in the Siddha system of medicine with biomedicine. So the study deals with the utilization of Siddha system of medicine, scientific validation of Siddha medicines, Siddha medicine research undertaken by biomedical practitioners and some government policies supporting mainstreaming of Siddha.
\end{abstract}

Keywords: Complementary medicine, Integrative medicine, Medical pluralism, Siddha, Traditional medicine

(C) 2020 The Authors. Published by Innovare Academic Sciences Pvt Ltd. This is an open access article under the CC BY license (http://creativecommons.org/licenses/by/4.0/) DOI: http://dx.doi.org/10.22159/ijpps.2020v12i4.36973. Journal homepage: https://innovareacademics.in/journals/index.php/ijpps

\section{INTRODUCTION}

Definition of integrative medicine (IM) is healingoriented medicine that takes account of the whole person, including all aspects of lifestyle. It emphasizes the therapeutic relationship between practitioner and patient, is informed by evidence and makes use of all appropriate therapies [1]. Based on the review and close reading of medical peer-reviewed journals and government health statistics, Null et al. [2] show that the number of people having In-hospital, adverse drug reactions (ADR) to prescribed medicine in the US is 2.2 million per year. The most stunning statistic, however, is that the total number of deaths caused by conventional biomedicine is 783,936 per year, far higher than the number of deaths attributable to heart disease in 2001 that was 699,697 and cancer that was 553,251. In India, neither do we have any statistics of damages caused by medicine, nor a procedure to record damages due to medical errors and iatrogenic effects. The increase in the prevalence of non-communicable diseases, drug resistance and pharmaceutical complications; growing dissatisfaction with the outcomes of certain biomedical treatments; and the gaps provide conventional health care to several segments of the population, have directed much attention to traditional, complementary and alternative medical (TCAM) systems [3]. This has led global population to conceive the idea of integration of Biomedicine with Traditional Medicine as it may mutually benefit both the medical systems in the form of filling up the gaps.

Indian traditional medicine is prevalent around the globe and integration exists scatterdly with modern medicine for different health needs [4]. Siddha system of medicine is one of the traditional medicines of India, practiced in the southern part of the country. It is a primordial system of medicine that existed in the world. Siddhars are the spiritual scientists; they are well versed in Metallurgy, Geology and Phytochemistry. They have used all kinds of herbs, metals, minerals and animal products vastly. In spite of their popularity, the rational design, proper standardization, and careful monitoring of traditional Indian formulations, along with tough scientific evidence, are essential for their promotion [4]. In our time there are lots of research are undertaken to bring out the scientific validation of Siddha medicine and they are published in national and international peer-reviewed journals. In AYUSH research portal around 1153 Siddha research articles, some of the research articles for various diseases are listed below (table 1).

Table 1: Some important clinical trials, pre-clinical trials done in Siddha system of medicine (scientific evidence)

\begin{tabular}{|c|c|c|c|c|}
\hline First author/year & Diseases & Study type/Sample size & Siddha Intervention & References \\
\hline Carlo Calabrese/2008 & $\begin{array}{l}\text { Cognitive performance, } \\
\text { Anxiety, Depression }\end{array}$ & $\begin{array}{l}\text { Randomized, Double-Blind, } \\
\text { Placebo-Controlled Trial (48) }\end{array}$ & Bacopa monnieri & {$[5]$} \\
\hline $\begin{array}{l}\text { Thanikachalam } \\
\text { Sadagopan/2014 }\end{array}$ & Diabetes & $\begin{array}{l}\text { Open, non-comparative, non- } \\
\text { randomized, phase IV clinical } \\
\text { trial (95) }\end{array}$ & Madhumega choornam (Internal) & {$[6]$} \\
\hline G. S. Lekha/2018 & Dengue & Cohort study (100) & Nilavembu Kudineer (Internal) & {$[7]$} \\
\hline Arul Mozhi P/2016 & Cerebral palsy & Phase II Clinical trial (210) & Brahmi nei (Internal) & [8] \\
\hline Sugunthan s/2017 & Cervical spondylosis & Phase II Clinical trial $(60)$ & $\begin{array}{l}\text { Vilvaver kudineer (Internal), } \\
\text { Varmam (Physical manipulation) }\end{array}$ & [9] \\
\hline Velpandian V/2013 & Osteoarthritis & Phase II Clinical trial (50) & $\begin{array}{l}\text { Gowri chinthamani chendhuram } \\
\text { (Internal medicine) }\end{array}$ & {$[10]$} \\
\hline Rajalakshmi S/2019 & Psoriasis & $\begin{array}{l}\text { Open, Comparative clinical trial } \\
(40)\end{array}$ & $\begin{array}{l}\text { Panchamuga chendhuram (Internal) } \\
\text { Kundavaathi thailam (External oil) }\end{array}$ & [11] \\
\hline
\end{tabular}




\begin{tabular}{|c|c|c|c|c|}
\hline $\begin{array}{l}\text { P. } \\
\text { Kamalasoundaram/2018 }\end{array}$ & $\begin{array}{l}\text { Dysfunctional uterine } \\
\text { bleeding }\end{array}$ & Phase II Clinical trial (40) & Perumbadukku pittu (Internal) & [12] \\
\hline Karthik nagarajan & Male infertility & $\begin{array}{l}\text { Open, Comparative Clinical trial } \\
(40)\end{array}$ & $\begin{array}{l}\text { Thetran ilagam (Internal) and Yoga } \\
\text { therapy }\end{array}$ & [13] \\
\hline $\begin{array}{l}\text { Subramaniyan } \\
\text { Sridhar } / 2018\end{array}$ & Osteoarthritis & Phase II Clinical trial (30) & Suttigai (Cauterization) & [14] \\
\hline Kingsley j/2018 & Rheumatoid arthritis & Phase II Clinical trial (20) & $\begin{array}{l}\text { Seendhil Chooranam (Internal) } \\
\text { Serankottai Nei }\end{array}$ & [15] \\
\hline Siva josyaa s/2018 & Urticaria & $\begin{array}{l}\text { Phase II Clinical trial } \\
(20)\end{array}$ & $\begin{array}{l}\text { Nilavagai Chooranam (Internal) } \\
\text { Sanjeevi Thylam (External) }\end{array}$ & [16] \\
\hline Bapat RD/1998 & Varicose ulcer & Phase II Clinical trial (20) & Attai vidal (Leech therapy) & [17] \\
\hline G. Ridhambaradevi/2018 & Cerebral palsy & Phase II Clinical trial (10) & $\begin{array}{l}\text { Brahmi nei (Internal medicine) } \\
\text { Podithimirthal (Dry powder } \\
\text { massage) }\end{array}$ & [18] \\
\hline P. Mirunaleni/2018 & Diabetes & Phase II Clinical trial (10) & Yoga therapy & [19] \\
\hline K. Samraj/2017 & $\begin{array}{l}\text { Benign Prostate } \\
\text { Hypertrophy }\end{array}$ & Case series (10) & Velvanga parpam (Internal) & [20] \\
\hline R. Gayatri/2019 & Renal calculi & Case series (2) & Nilavembu Kudineer (Internal) & [21] \\
\hline Natrajan/2019 & $\begin{array}{l}\text { Acute avulsion of } \\
\text { posterior cruciate } \\
\text { ligament of knee with } \\
\text { bone fragment }\end{array}$ & Case study & Varmam (Physical manipulation) & [22] \\
\hline Lalitha sivasankaran/2019 & Tennis elbow & Case study & Attai vidal (Leech therapy) & [23] \\
\hline L. Janani/2018 & Insomnia & Case report & Varmam (Physical manipulation) & [24] \\
\hline G. S. Lekha/2018 & Tinea infection & Case study & $\begin{array}{l}\text { Sivanaramritham (Internal) } \\
\text { Thriphala chooranam (Internal) } \\
\text { Karbogi paste (External) }\end{array}$ & [25] \\
\hline Sivakkumar S/2018 & Varicose ulcer & Case study & Pugai (Fumigation) & [26] \\
\hline Aruna devi R/2018 & Diabetic Ulcer & Preclinical study & Matthan thailam (External) & [27] \\
\hline Kumaravel Appavoo/2019 & Peptic ulcer & Preclinical study & Sirucinni Uppu (Internal) & [28] \\
\hline ChristianGJ/2014 & Peptic ulcer & Preclinical study & Anda leghyam (Internal) & [29] \\
\hline Sivaranjani K/2016 & $\begin{array}{l}\text { Musculoskeletol } \\
\text { disorders }\end{array}$ & Review & Varmam (Physical manipulation) & [30] \\
\hline S. Bhavani/2017 & Hepatitis-B & Review & Internal medicine & [31] \\
\hline Dharani/2016 M & Hemorrhoids & Review & Pugai (Fumigation) & [32] \\
\hline Chitra, Beyaril/2015 & Senile Dementia & Review & Internal medicine & [33] \\
\hline B K Priya/2018 & Sinusitis & Review & Nasiyam (Nasal instillation) & [34] \\
\hline $\begin{array}{l}\text { Ananthalakshmi } \\
\text { ramamoorthy/2015 }\end{array}$ & Oncology & Review & Internal medicine & [35] \\
\hline Jeeva gladys. R/2013 & Oncology & Review & Internal medicine & [36] \\
\hline
\end{tabular}

Table 2: Utilization of siddha system of medicines in siddha OPDs around Tamil Nadu

\begin{tabular}{|c|c|c|c|c|c|}
\hline 1st $^{\text {st }}$ uthor & $\begin{array}{l}\text { Sample size } \\
\text { Male/Female n (\%) }\end{array}$ & Place/Duration of the study & Morbidities n (\%) & & References \\
\hline Kanna et al. & $\begin{array}{l}1511 \\
\text { Male } 1070(73) \\
\text { Female } 411(27)\end{array}$ & $\begin{array}{l}\text { Special } \\
\text { Geriatric Clinic, Siddha } \\
\text { Central Research Institute, } \\
\text { Chennai/January to } \\
\text { December } 2009\end{array}$ & $\begin{array}{l}\text { Skin diseases } \\
\text { Genital Disorder } \\
\text { Fever } \\
\text { Musculoskeletal disorders } \\
\text { Alimentary Canal diseases } \\
\text { Respiratory Diseases } \\
\text { Diabetes } \\
\text { Cardiac Diseases } \\
\text { Eye diseases }\end{array}$ & $\begin{array}{l}113(7.4) \\
3(0.2) \\
4(0.26) \\
300(20) \\
50(3.3) \\
119(7.88) \\
84(5.56) \\
10(0.66) \\
2(0.13)\end{array}$ & {$[38]$} \\
\hline $\begin{array}{l}\text { Selva Raj k et } \\
\text { al. }\end{array}$ & $\begin{array}{l}763 \\
\text { Male } 445(58.3) \\
\text { Female 318(41.7) }\end{array}$ & $\begin{array}{l}2 \text { Siddha OPD (Andhiyur and } \\
\text { Bhavani Government } \\
\text { Hospitals), Erode District, } \\
\text { Tamil Nadu, India./June-July } \\
2014\end{array}$ & $\begin{array}{l}\text { Arthritis } \\
\text { Neuritis } \\
\text { Diabetes } \\
\text { Bronchial Asthma } \\
\text { Hemiplegia } \\
\text { Eczema } \\
\text { Acid peptic Ulcer } \\
\text { Lumbar Spondylosis } \\
\text { Ulcer } \\
\text { Allergy }\end{array}$ & $\begin{array}{l}345(45.2) \\
67(8.8) \\
50(6.6) \\
40(5.2) \\
28(3.7) \\
25(3.3) \\
22(2.9) \\
19(2.5) \\
16(2.1) \\
15(2)\end{array}$ & [39] \\
\hline $\begin{array}{l}\text { M M Reddy et } \\
\text { al. }\end{array}$ & $\begin{array}{l}227 \\
\text { Males } 138(60.8) \\
\text { Female } 89(39.2)\end{array}$ & $\begin{array}{l}2 \text { Siddha OPD (Andhiyur and } \\
\text { Bhavani Government } \\
\text { Hospitals), Erode District, } \\
\text { Tamil Nadu, India, } 2015\end{array}$ & $\begin{array}{l}\text { Fungal Infection } \\
\text { Primary Complex } \\
\text { Bronchitis } \\
\text { Diarrhoea }\end{array}$ & $\begin{array}{l}65(24.2) \\
49(21.6) \\
29(10.1) \\
13(8.4)\end{array}$ & {$[40]$} \\
\hline $\begin{array}{l}\text { V. Duraisamy } \\
\text { et al. }\end{array}$ & $\begin{array}{l}1720 \\
\text { Male } 807(46.9) \\
\text { Female } 913(53.1)\end{array}$ & $\begin{array}{l}2 \text { Siddha OPD, (Andhiyur and } \\
\text { Bhavani Government } \\
\text { Hospitals), Erode District, } \\
\text { Tamil Nadu, India/February, } \\
2014 \text {. }\end{array}$ & $\begin{array}{l}\text { Arthritis } \\
\text { Neuritis } \\
\text { Fungal diseases } \\
\text { Bronchitis } \\
\text { Acid peptic diseases }\end{array}$ & $\begin{array}{l}362(21) \\
172(10) \\
116(6.7) \\
114(6.6) \\
109(6.3)\end{array}$ & {$[41]$} \\
\hline
\end{tabular}




\section{Utilization of siddha system of medicines}

In a study Shalini Rudra et al. explore the out-of-pocket expenditure on AYUSH treatment. The result shows that, the average expenditure on AYUSH medicines is Rs 270 in rural and Rs 378 in urban areas and is lower than average expenditure on non-AYUSH (allopathic) medicine [37]. This study focuses on AYUSH and lacks individual System wise which is warranted. To explore the integrative medicine, it is vital to understand the feasibility, efficacy and acceptability of Siddha interventions among the public. Some of the studies in Siddha OPDS around Tamil Nadu are listed below (table 2). The common use of Siddha medicines is for skin diseases, musculoskeletal disorder, diabetes, Respiratory diseases, gastrointestinal diseases.

\section{Various siddha medicine research conducted by biomedicine practitioners}

1. Thanikachalam et al., conducted a study to evaluate the clinical efficacy and safety of the polyherbal compound MMC in the management of type 2 diabetes. This pilot study was an open, noncomparative, non-randomized, phase IV clinical trial, conducted at the PURSE-HIS research station, at Sri Ramachandra University, Porur, Chennai, India from January 2008-2010. The trial included 95 patients; the results revealed that the fasting, postprandial blood glucose, HbA1c showed significant reduction after MMC intervention. The liver, renal functions, along with the hematological parameters were well within the normal range[6].

2. Govindan et al. conducted a study on the clinical efficacy of Solanum xanthocarpum and Solanum trilobatum in bronchial asthma at Madras medical college; the results revealed that improvement in Peak expiratory Flow rate (PEFR) and the reduction in other symptom scores clearly show a bronchodilator effect, a decrease of edema and secretions in the airway lumen. The response to these herbs, equal to that of deriphylline but less than salbutamol [42].

3. P. M. Murali et al., conducted a randomized, double-blind study with Plant-based formulation (DCBT1234-Lung KR) in the management of chronic obstructive pulmonary disease, result revealed that, Improved PaO2 was observed in $15.4 \%$ of DCBT1234Lung KR patients while no improvement was seen with patients in any other arms. Symptoms like dyspnoea, wheezing, cough, expectoration, disability and sleep disturbances also considerably reduced in DCBT1234-Lung KR and the biomedical group patients, but not in the placebo arm. DCBT1234-Lung KR was alike, but not better than the present-day treatment with salbutamol, theophylline and bromhexine combination in COPD patients and this was ascertained using FEV1 and ABG values [43].

4. P. M. Murali et al., conducted a controlled clinical trial to compare plant-based formulation (DCBT4567-Astha-15) efficacy with oral salbutamol and theophylline for Bronchial Asthma, the results revealed that DCBT4567-Astha-15 was as efficacious as salbutamol $(12 \mathrm{mg} /$ day $)$ in combination with theophylline $(200$ $\mathrm{mg} /$ day) treat reversible asthmatics. Quality of life of patients also improved with DCBT4567-Astha-15 drug treatment [44].

5. Chidambaram s. babu et al., conducted a trial on Venthamarai chooranam, a polyherbal Siddha medicine, alleviates hypertension via AT (1)R and eNOS signaling pathway in $2 \mathrm{~K} 1 \mathrm{C}$ hypertensive rats, 2014 in Ramachandra University, Porur, Chennai, India. The result shows, Venthamarai chooranam potentially interacts with reninangiotensin components and endothelial functions, and antihypertensive action[45].

6. Chidambaram s. babu et al., conducted a study on Polyphenols in madhumega chooranam, a Siddha medicine, ameliorates carbohydrate metabolism and oxidative stress in type II diabetic rats in Ramachandra University, Porur, Chennai, India. The results revealed that Madhumega chooranam mediates its anti-diabetic action through the inhibition of gluconeogenesis and activation of glycolytic pathways in type II diabetic rats. Increased GLUT4 and PPARy expressions provide more information on its glucose uptake/sensitising and hypolipidemic potential [46].

7. KR Subash et al. conducted the study in Sri venkateshwara institute of medical science, tirupati, Andhra Pradesh, India. They evaluated the analgesic activity of Alpinia galanga extract in mice models and TNF-alpha receptor computational docking analysis on its leads with pharmacokinetics prediction. The results showed Alpinia galanga extract had significant antinociceptive activity and followed by computational analysis of 20 compounds with known chemical structure predicted Galanal B as a lead compound with best in-silico pharmacokinetic and drug-like features [47].

8. R. V. Ramanarayana Reddy et al. conducted the study at Melmaruvathur Adhiparasakthi Institute of Medical Sciences and Research, Tamil nadu, India. Evaluation of the antidiabetic activity of polyherbal formulation of Seenthil churnam in Alloxan induced diabetic rats. Administration of alcohol extract of Seenthil Churnam produced a dose-dependent decrease in blood glucose levels in Alloxan induced rats. There was a significant fall in blood sugar level in the dose of $300 \mathrm{mg} / \mathrm{kg}$; this is comparable to the effect of Glibenclamide [48].

9. Thyagarajan SP et al. conducted a trial in CMC Hospital, vellore, India. 24 healthy long-term HBV carriers were treated with phyllanthus amarus and placebo; the result shows HBsAg clearance and HBV-DNA levels were significantly reduced [49].

10. J. Saikarthik et al. conducted the trial in Saveetha medical college and hospital, Chennai, Tamilnadu, India. Phytochemical analysis of methanolic extract of seeds of Mucuna pruriens by gas chromatography-mass spectrometry; the analysis reveals the presence of 5 major compounds namely, pentadecanoic acid, 14methyl-, methyl ester, dodecanoic acid, 9,12-octadecadienoic acid $(\mathrm{z}, \mathrm{z})-$, methyl ester, 9,12-octadecadienoic acid and 2-myristynoylglycinamide which are therapeutically potential [50].

These examples show how the benefits of Siddha medicines could be brought into the mainstream health care where they are balanced to play an increasingly important role.

\section{Government health policies for mainstreaming of siddha}

Several policies which may help to integrate Siddha medicine for health care system are listed below,

1. Udupa Committee in its report published in 1958 recommended that there is a need for integrated system of medicine in India [51].

2. The National Population Policy 2000, National Health Policy 2002, and the National Commission on Macroeconomic and Health-2005 of the Ministry of Health and Family Welfare, Government of India, emphasized on reorientation and prioritization of research in Ayurveda, Yoga and Naturopathy, Unani, Siddha and Homoeopathy (AYUSH) and to confirm therapy and drugs in chronic and lifestyle-related diseases [52,53].

3. The National Health Policy (NHP) 2017 has strongly advocated mainstreaming the potential of AYUSH within a pluralistic system of Integrative health care. The NHP 2017 uses a new language of 'medical pluralism' and re-emphasizes the need for integrating AYUSH in the National Health Mission, research and education. Indeed, the NHP 2017 is the most powerful policy expression of integrative healthcare since independence for which the Ministry of Health and Family Welfare must be congratulated. NHP 2017 highlights strategies to meet national health goals through protocol driven integrative practices [54].

4. Ministry of AYUSH, along with Directorate General of Health Services (DGHS) is implemented NPCDCS (National Programme for Prevention and Control of Cancer, Diabetes, Cardiovascular Diseases and Stroke) for health promotion, prevention and management of Noncommunicable diseases or Lifestyle related disorders [55].

\section{Nilavembu kudineer}

At the time of dengue epidemic 2012, the Tamil Nadu government distributed a Siddha herbal decoction, Nilavembu kudineer (NVK) at free of cost. Health and Family Welfare Department letter No. 41459/IM1(2)/2012, dated 21.11.2012 stated that "Nilavembu decoction, traditional Siddha drug is effective in the treatment of viral fevers like dengue". The Nilavembu kudineer has 9 ingredients they are Nilavembu (Andrographis paniculata), Vilamichai Ver 
(Plectranthus vettiveroides), vetiver (Vetiveria zizanioides), Cukku (Zingiber officinale), Milagu (Piper nigrum), Korai kizhangu (Cyperus rotundus), Santanam (Trichosanthes cucumerina), Parpadagam (Mollugo cerviana). This is not only to treat diseases, but also to prevent diseases [56]. As a result, there is a reduction in morbidity and mortality of dengue fever. The antiviral activity of nilavembu kudineer was estimated by Jaspreet jain et al. [57], dengue and chikungunya virus through in vitro evaluation shows, NVK provides protection against CHIKV and DENV-2 during active infection and also help to prevent virus infection in the cells.

\section{Amma magapeeru sanjeev kit}

For the first time, drugs of Siddha systems have been incorporated into the kits of ante-natal cases throughout the state of Tamilnadu. Health and Family Welfare Department Demand No.19 Policy Note 2016-17 stated that Amma maperu sanjeevi, at Rs. 10 crore scheme, which will have a bouquet of 11 siddha medicines for pregnant women and newborn." A kit contains Madhulai Manappagu, Karuveppilai Podi, Nellikkai Legiyam, Elathy tablet, Annabedhi tablet, Ulundhu thailam and Pinda Thailam (both for external application), Paavana Panchakula thailam, sathavari legium, kunthiriga thailam, Urai mathirai. These medicines will reduce nausea, vomiting, balancing iron deficiency, reducing false pain, improve immunity in infants. This helps the health systems to take care of many of women and children as a first line of care through the Siddha medicine [58].

\section{Areas of focus in integration}

\section{Varmam (Physical manipulation)}

In biomedicine, the treatment for musculoskeletal disorders are local injections of steroids, Nonsteroidal anti-inflammatory drugs (NSAIDs), opioids, antidepressants, muscle relaxants are either ineffective or provide short-lasting benefits [59]. With this hitch the medical industry is in need of effective, long lasting benefits in musculoskeletal disorders. Siddha varmam therapy originated from the southern part of Tamilnadu, is now practiced in South Asian countries like India, Srilanka and Malaysia. Varmam specifies the therapeutic manipulation of certain points in which the life energy is found pooled. Handling on these points with a particular force for the definite time will release the life energy from these points and fetch relief to the affected individual by regulating the flow of life energy which is blocked due to attack on particular Varmam points or due to other causes [22]. It offers a conservative management approach to pain, Neuro-musculoskeletal disorders, metabolic disorders, sensory defects, gastrointestinal, respiratory diseases, endocrine disorders, pediatric diseases like autism and trauma $[9,22,24,30]$. The advantages of varmam are non-invasive technique, cost effective, easy to manipulate. Siddha varmam therapy may open new perspectives in the area of pain management. A national Guidelines to Practice varmam is available in India published by CCRS (Central Council for research in Siddha), Ministry of AYUSH, Government of India [60].

\section{Karanool sigichai (Chemical cauterization)}

Karanool sigichai is a unique para surgical treatment carried out for the management of fistula-in-ano. It is a method of chemical cauterization of fistula. Achyranthus salt, Dalmia extensa salt etc. are smeared on a surgical thread which is used to cut the tract. The major advantages of this procedure are, it will preserve the function of continence and prevents the recurrence of the condition and also cost effective $[61,62]$. This will open up a new scope of Siddha parasurgical procedure in Anal fistula.

\section{Attai vidal (Leech therapy)}

In the Act of June 28, 2004, the Food and Drug administration (FDA) cleared for the first time the commercial marketing of medicinal leeches for medicinal purposes and determined that leeches are medical devices. In Siddha text leech therapy, especially indicated for edema, headache, abdominal pain caused by dysentery, whooping cough in children, inflammatory joint diseases, eye diseases. Bio-constituents in leech saliva have vasodilator, anesthetic, anti-inflammatory activity and also inhibits the blood coagulation [63]. Leech therapy is used clinically for various diseases they are Osteoarthritis, Epicondylitis, varicose veins, and hematoma. It is also evident leech was used in dreadful condition, menigococcal purpura. As an integrative approach now leech is used in bone reconstruction surgery.

\section{Yoga}

The term 'Yogam' means 'union'. Siddhars have defined yogam as an art which controls the mind by preventing it from distracting through sense and sense organs and fuse it with the divinity. The eight steps or stages of yogam arelyamam (Learning discipline), Niyamam (Purity of action), Asanam (posture), Pranayamam (controlling one's breath), Prathyaharam (Controlling 5 senses), Dharanai (the practice of concentration), Dhyanam and Samadhi. Third step or stage of yogam is asanam, means posture or pose, it is also called as yogasanam. The perfect and scientific art of controlling one's breathing is called Pranayamam. It is also called as 'vasi' and 'vasiyogam [64]. Yoga can be integrated with various diseases such as Musculoskeletal disorders, Bronchial asthma [65], hypertension [66], depression, insomnia etc $[13,19]$. It can also be used as an adjuvant therapy for many non-communicable diseases.

\section{DISCUSSION}

The concept of 'integrative' medicine has come up several times earlier and is not new. This, however is not a call for Siddha alone, but it is all about the direction of change. World Health Organization (WHO) has announced desirable doctor-population ratio as 1:1,000. In India as per current population, it gives a doctor (modern medicine) and a population ratio of $0.77: 1,000$ [65]. After considering AYUSH registered medical practitioners it counts, 1.33 billion of Indian population is being served by 1.8 million registered medical graduates during 2017. So, the ratio is 1.34 doctor for 1,000 Indian citizens as of 2017. This shows that India reached WHO norm by 1:1,000 doctor population ratio after considering AYUSH doctors. Besides this an assessment of the mainstreaming of AYUSH in Rajasthan, India [Society for Economic Development and Environmental Management (SEDEM) n. d.], revealed that AYUSH is popular and regularly accessed by the community. Approximately half the allopathic doctors studied reported never referring patients to AYUSH doctors 3 the lack of knowledge about traditional medicine in biomedicine practitioner is the reason behind this crisis; this can be rectified by including traditional medicine in the MBBS curriculum itself.

The Indian government also supports to promote the traditional medicine in India. The budget al. location for the Dept of AYUSH has increased gradually over the years. In the 12th Five Year Plan of India (2012-2017), the total allocation for AYUSH was INR. 10,044 crore, which was $235 \%$ more than the actual expenditure of 11 th Plan [66]. Till date, AYUSH facilities have been co-located in 506 District Hospitals, 374 sub district Hospitals, 2871 CHCs, 8995 PHCs, and 5716 other healthcare centers. The Magnitude of AYUSH infrastructure in the country has reached 7,99,879 registered practitioners, said by the AYUSH minister on 19 July 2019 [67, 68].

Although we have proof of scientific validation, the utilization of Siddha medicines for various diseases, the data for Siddha Intervention as Add-on, limitations for Siddha intervention (Dislodgement of renal calculi of bigger size), areas where Siddha can compliment such as usage of Mathan thylam in diabetic ulcer without disturbing the contemporary treatment module, drug-drug interactions, drug food interactions and food based health benefits have to be documented. The discovery of complete integrative approach guidelines of Siddha medicine with biomedicine is the only approach to resolve this crisis. Both Siddha and biomedicine experts in a particular field should assemble and prepare the guideline to safeguard the public.

\section{CONCLUSION}

Hence, there has been a huge utilization of Siddha medicine and also proof of scientific validation of Siddha medicine its usage in both communicable and non-communicable diseases, Integrating Siddha medicine with biomedicine is essential to offer better health facilities to public. Integration of Siddha with the existing health care 
system, not only helps in preventive and promotive health also focuses more in complementing Biomedicine by offering profound Siddha Varmam, Yoga therapy. Integrative approach is the only way to achieve the dream of health in an efficacious and cost effective manner.

\section{FUNDING}

Nil

\section{AUTHORS CONTRIBUTIONS}

All the authors have contributed equally.

\section{CONFLICT OF INTERESTS}

Nil

\section{REFERENCES}

1. Andrew weil center for integrative medicine, University of arizona, National center for. Available from: https://integrativemedicine.arizona.edu/about/definition.html [Last accessed on 15 Dec 2019]

2. Null G, Carolyn Dean, Martin Feldman, Debora Rasio, Dorothy Smith. Death by medicine. Virginia: Praktikos Books; 2010.

3. Lakshmi JK, Nambiar D, Narayan V, Sathyanarayana TN, Porter J, Sheikh K. Cultural consonance, constructions of science and co-existence: a review of the integration of traditional, complementary and alternative medicine in low-and middleincome countries. Health Policy Plan 2015;30:1067-77.

4. Sen S, Chakraborty R. Toward the integration and advancement of herbal medicine: a focus on traditional Indian medicine. Botanics: Targets Therapy 2015;5:33-44.

5. Calabrese C, Gregory WL, Leo M, Kraemer D, Bone K, Oken B. Effects of a standardized Bacopa monnieri extract on cognitive performance, anxiety, and depression in the elderly: a randomized, double-blind, placebo-controlled trial. J Altern Complement Med 2008;14:707-13.

6. Thanikachalam Sadagopan, Anbarasi Chandrasekharan, Harivanzan Vijayakumar, Saravanababu Chidambaram, Bhaskar VKS Lakkakula. Efficacy and safety profile of siddha compound madhumega choornam (MMC) in type II diabetic patients. Int J Pharm Res Scholars 2014;3:322-9.

7. GS Lekha. An interventional cohort study in dengue prevalent area by using nilavembu kudineer and awareness programme. IOSR J Dental Med Sci 2018;17:19-23.

8. Arul Mozhi P, Pattarayan R, Deivanayagi. S, Banumathy V. Analytical standardization of brahmi nei and effect of siddha methodologies on spasticity in cerebral palsy. Int J Curr Res Med Sci 2016;2:82-9.

9. Sugunthan S, Shailaja R, Mohamed Musthafa. A comparative clinical study on villaiver kudineer and varmam therapy in the treatment of cervical spondylosis. Eur J Pharm Med Res 2017;4:392-8

10. V Velpandian, M Pitchiah Kumar, N Anbu, Md Musthafa, K Kanakavalli. Clinical evaluation of siddha drug gowri chinthamani chendooram in the management of osteoarthritis 2. Int J Pharm Sci Invent 2013;1:26-32.

11. S Rajalakshmi, Sathya Rajeswaran, K Samraj. An open comparative clinical trial to evaluate the efficacy and safety of siddha drugs panchamuga chendhuram and kundavaadhi thailam in psoriasis. Int J Res Ayurveda Pharm 2019;10:77-82.

12. $\mathrm{P}$ Kamalasoundaram, $\mathrm{T}$ Lakshmikantham, $\mathrm{K}$ Manikavasagam. Clinical evaluation of siddha medicine perumpadukku pittu in the treatment of pitha perumpadu (Dysfunctional Uterine Bleeding). Int J Curr Res Chem Pharm Sci 2018;5:14-21.

13. Karthik Nagarajan S, S Nagalakshmi, NJ Muthu Kumar, V Banumathi. A comparative clinical trial of siddha poly herbal formulation thetran ilagam (internal) and yogam therapy in the management of aan maladu (male infertility). World J Pharm Res 2019;8:878-93.

14. Subramaniyan Sridhar. Efficacy of classical siddha external therapy "Suttigai" (Thermal Cauterization) on azal keel vaatham. IOSR J Dental Med Sci (IOSRJDMS) 2018;17:1-11.

15. Kingsley J, Arun Kumar G, Sivakkumar S, Mariappan A, Visweswaran S, Banumathi V. 6 a pilot study on "combination of siddha formulation" in the treatment of "vali azhal keel vayu" (rheumatoid arthritis). World J Pharm Res 2018;7:1299-307.

16. Siva Josyaa S, Muthukumar NJ, Banumathi V. A pilot study of siddha drug nilavagai choornam (internal) and sanjeevi thylam (external) for the treatment of kanakadi (urticaria). World J Pharm Res 2018;7:1291-8.

17. Bapat RD, Acharya BS, Juvekar S, Dahanukar SA. Leech therapy for complicated varicose veins. Indian J Med Res 1998;107:281-4.

18. G Ridhambaradevi, R Vinodini, M Meenakshi Sundaram, V Banumathi. Clinical evaluation of a siddha preparation brahmi nei (internal medicine) and kollu podi thimirthal (external) in the treatment of sirasthambavaatham (cerebral palsy)-a pilot study. World J Pharm Res 2018;7:1435-43.

19. P Mirunaleni, Narmadha Jothinathan A, Shakthi Paargavi, Bhavani Balakrishnan. Effect of integrative approach using siddha medicines, isha yoga and dietary modifications in treatment of madhumegam (Diabetes mellitus) in holistic approach observational study. Int J Curr Res Chem Pharm Sci 2018;5:9-12.

20. K Samraj, K Kanakavalli Principal, P Sathiyarajeswaran. The siddha drug velvanga parpam intervention in the management of benign prostatic hyperplasia (bph): a case series. Indian J Appl Res 2017;7:74-6.

21. R Gayatri, BK Priya, S Vinayak S, S Elansekaran, M Ramamurthy, V Srinivasan, et al. Efficacy of nilavembu kudineer for treating renal calculi: a case series. Int J Trans Res Ind Med 2019;1:20-4.

22. S Natarajan, C Anbarasi, R Meena, SD Muralidass, $P$ Sathiyarajeswaran, K Gopakumar, RS Ramaswamy. Treatment of acute avulsion of posterior cruciate ligament of left knee with bony fragment by Siddha Varmam therapy and traditional bone setting method. J Ayurveda Integr Med 2019;10:135-8.

23. Lalitha Sivasankaran, V Anavarathan, V Mahalakshmi, D Periyasami, NJ Muthukumar, V Banumathi. Pain management of attai vidal (leech therapy) in siddha system of medicine on lateral epicondylitis (tennis elbow). World J Pharm Res 2019;8:809-14.

24. L Janani, Tushita Thakur. Insomnia as a presentation of depression managed with siddha varmam therapy and homoeopathic medicine: a case report. Eur J Pharm Med Res 2018;5:451-5.

25. GS Lekha, A Kanagarajan. Management of dermatophytosis or padarthamarai in siddha system-a case study. World J Pharm Res 2018;7:1264-71.

26. Sivakkumar S, Juliet L, Banumathi V. Effect of classical herbomineral siddha formulation Agasthiyar kuzhambu fumigation therapy on silaipun (varicose ulcer)-a case study. Int J Pharm Sci Res 2018;9:1189-93.

27. Arunadevi R, Susila R, Murugammal S, Divya S. Preparation and standardization of mathan tailam: a classical siddha formulation for diabetic ulcerative wound healing. J Ayurveda Integr Med 2018. Doi:10.1016/j.jaim.2017.08.011

28. Kumaravel Appavoo, Mudiganti Ram Krishna Rao. Treatment of peptic ulcers with a Siddha medicine, "Sirucinni Uppu" and prediction with regression models. Informatics Medicine Unlocked 2019;15:100169.

29. Christian GJ, Mubarak H, Yamini K, Onesimus T, Elansekaran S, Vennila $\mathrm{K}$, et al. Anti-ulcer efficacy and safety of and a leghyam a polyherbal siddha formulation. Int J Pharm Sci Res 2014;5:1837-42.

30. K Sivaranjani Varma. Therapy for musculoskeletal disorders. Eur J Pharm Med Res 2016;3:131-5.

31. S Bhavani. Hepato-protective herbs and medicines in siddha system of medicine-a review. J Pharmacogn Phytochem 2017;6:2246-51.

32. Dharani, M Alamelu, J Sabira Sherin, K Merish, S Walter, Thomas M. Role of pugai (fumigation) in siddha system. World Siddha Day Special 2016;1:1-10.

33. B Chitra, Ramasamy RS. An overview on the role of siddha practices in the prevention and management of age related neurodegenerative disorders with special reference to senile dementia. Indo Am J Pharm 2015;5:1510-21.

34. BK Priya, S Elansekaran, M Ramamurthy, V Srinivasan, M Kanniyakumari, GJ Christian. A review on siddha external therapy-nasiyam (Nasal Instillation). Int J Ayur Pharm Res 2018;6:47-53. 
35. Ananthalakshmi Ramamoorthy, Sunitha Janardhanan, Sathiyajeeva Jeevakarunyam, Nadheem Jeddy, Senthil Eagappan. Integrative oncology in indian subcontinent: an overview. J Clin Diagn 2015;9:1-3.

36. Jeeva Gladys R, Kalai Arasi R, Elangovan S, Mubarak H. Screening of siddha medicinal plants for anti cancer activity-a review. J Appl Pharm Sci 2013;3:176-82.

37. Shalini Rudra, Aakshi Kalra, Abhishek Kumar, William Joe. Utilization of alternative systems of medicine as health care services in India: evidence on AYUSH care from NSS 2014. PLoS One 2017;12:0176916.

38. Kannan M, Natarajan $S$, Sathiyarajeswaran $P$, Meenakshisundaramurthy K. The health status of geriatric population attending the special siddha geriatric clinic of a research institute. Int J Health Pharm Sci 2012;1:36-41.

39. Selvaraj K, Srinivasan M, Duraisamy V, Ramaswamy G, Venugopal V, Chinnakali P. Morbidity profile of elderly outpatients attending selected sub-district Siddha health facilities in Tamil Nadu, India. Ancient Sci Life 2016;35:212-6.

40. Reddy MM, Nair D, Duraisamy V, Selvaraj K, Chinnakali P, Saya GK. Morbidity profile of children attending Siddha hospitals in a district of Tamil Nadu, South India. Int J Contemp Pediatr 2015;2:168-71.

41. Venkatachalam Duraisamy, Pruthu Thekkur, Marie Gilbert Majella, Manikandan Srinivasan, Ganesh Kumar Saya, et al. Morbidity profile of adult outpatients attending traditional medicine health facilities in a district of South India. J Ayurveda Integr Med 2018;9:281-4.

42. Govindan S, Viswanathan S, Vijayasekaran V, Alagappan R. Further studies on the clinical efficacy of Solanum xanthocarpum and Solanum trilobatum in bronchial asthma. Phytother Res 2004;18:805-9.

43. Panchapagesa, Murali, Rajasekaran, Sikhamani, Paramesh P, R Krishnarajasekar 0 , et al. Plant-based formulation in the management of chronic obstructive pulmonary disease: a randomized double-blind study. Respir Med 2006;100:39-45.

44. Panchapagesa Murali, Rajasekaran Sikhamani, Krishnarajasekar OR, Thiyagarajan Perumal, Krishna Nalini, Lakshmisubramanian $\mathrm{S}$, et al. Plant-based formulation for bronchial asthma: a controlled clinical trial to compare its efficacy with oral salbutamol and theophylline. Respiration: Int Rev Thoracic Diseases 2006;73:457-63.

45. Saravana Babu C, Sathiya S, Anbarasi C, Prathyusha $\mathrm{N}$, Ramakrishnan G, Kalaivani P, et al. Polyphenols in madhumega chooranam, a Siddha medicine, ameliorates carbohydrate metabolism and oxidative stress in type II diabetic rats. J Ethnopharmacol 2012;142:331-6.

46. S Babu, Chidambaram Kalaivani, Periyathambi Ranju, Vijayan Sekar, Sathiya Chandrasekaran, Anbarasi V Mahadevan, et al. Venthamarai chooranam, a polyherbal siddha medicine, alleviates hypertension via ATR and eNOS signaling pathway in 2K1C hypertensive rats. Exp Biol Med 2014;239:758-69.

47. Subash KR, Britto GF, Kumar KS, Umamaheshwari A, Konda VCR, Prakash BG. Analgesic activity of Alpinia galanga extract in mice models and TNF-alpha receptor computational docking analysis on its leads with pharmacokinetics prediction. Int J Basic Clin Pharmacol 2018;7:446-50.

48. RV Ramanarayana Reddy. Evaluation of antidiabetic activity of polyherbal formulation seenthil churnam in alloxan induced diabetic rats. World J Pharm Res 2016;3:4739-46.

49. Thyagarajan Sp, Jayaram S, Panneerselvam A. Effect of phyllanthus amarus, an Indian medicinal plant on healthy carriers of hepatitis B virus: Results of six clinical trials. Indian J Gastroenterol 1999;18 (Suppl 1):1990-6.

50. Saikarthik J, Ilango S, Kumar JV, Vijayaraghavan R. Phytochemical analysis of methanolic extract of seeds of Mucuna pruriens by gas chromatography mass spectrometry. Int J Pharm Sci Res 2017;8:2916-21.

51. Sulochana Bhat, Saketh Ram Thrigulla, N Srikanth, MM Padhi, Kartar Singh Dhiman. Integration of ayurveda with biomedicine: a response identification cross sectional survey. Ayushdhara 2015;2:1-5.

52. The National Population Policy. Department of Family Welfare, Ministry of Health and Family Welfare, Govt. of India. New
Delhi: The National Population Policy; 2000. Available from: http://mohfw.nic.in/sites/default/files/26953755641410949 469\%20\%281\%29.pdf. [Last accessed on 23 Aug 2017]

53. National Health Policy. Ministry of Health and Family Welfare, Govt. of India. New Delhi: National Health Policy; 2002. Available from: http://mohfw.nic.in/sites/default/files/18048892912105179 110National.pdf. [Last accessed on 23 Aug 2017]

54. Darshan Shankar, Bhushan Patwardhan. AYUSH for New India: vision and strategy. J Ayurveda Integr Med 2017;8:137-9.

55. Renu Singh, Sarada Ota, Shruti Khanduri, Sandhya Rani, Arun Bhadula. Integration of AYUSH (Ayurveda and Yoga) with national programme for prevention and control of cancer, diabetes, cardiovascular diseases and stroke (NPCDCS): An appraisal of central council for research in ayurvedic sciences research and development initiatives. J Res Ayurvedic Sci 2018;2:27-36.

56. Tamil Nadu government provides a herbal cure for dengue, Biospectrum. Available from: https://www.biospectrumindia.com/news/77/9690/tamilnadu-government-provides-a-herbal-cure-for-dengue. html [Last accessed on 19 Oct 2017]

57. Jaspreet Jain, Ankit Kumar, Vimal Narayanan, RS Ramaswamy, P Sathiyarajeswaran, MS Shree Devi, et al. Antiviral activity of ethanolic extract of nilavembu kudineer against dengue and chikungunya virus through in vitro evaluation. J Ayurveda Integr Med 2019;S0975-9476:30073-1.

58. Amma Magaperu Sanjeevi scheme launched by Chief Minister J Jayalalithaa, Chennai live. Com. Available from: https://www.livechennai.com/detailnews.asp?newsid=23779 [Last accessed on 12 Jan 2016]

59. Curatolo M, Bogduk N. Pharmacologic pain treatment of musculoskeletal disorders: current perspectives and future prospects. Clin J Pain 2001;17:25-32.

60. RS Ramaswamy, P Sathiyarajeswaran, M kannan, S Natarajan, R Meena. Guidelines for practice of siddha varmam therapy, Central council for research in Siddha, Chennai, 1st edition; 2017.

61. Jeyavenkatesh J, Elango V, Rojaramani S, Saravanapandian P, Senthinathan S. Clinical and experimental approach for karanool sigitchai in velimoolam (External haemorrhoid) and pouthiram (Low anal fistula). Case Study Alternative Med 2017;114:34-8

62. R Vidhya, B Vinubharathi, NJ Muthukumar, MV Mahadevan, V Banumathi. Effectiveness of karanool therapy application on pilonidal sinus (Purai pun)-a case study. Int J Curr Res Med Sci 2018:4:31-5.

63. Wilson, Eugene, R Rajasekaran, A Narayana. Hirudo-therapy in the past and its future potential. J Indian Med Heritage 2010;1:49-72.

64. Yoga in siddha-central council for research in siddha. Available from:

http://siddhacouncil.com/downloads/yoga_in_siddha.pdf. [Last accessed on 10 Dec 2019]

65. Arpan A Bhatt, Shweta Pandey, Brajesh Singh, Gauravi Vyas, Gyanendra Datta Shukla, Upasna Gulati. The role of yoga therapy in the management of bronchial asthma (Tamaka shwasa). Asian J Pharm Clin Res 2019;12:27-33.

66. Premalatha P, Kanniammal C, Valli G, Jaydeep Mahendra. Effect of physical exercise and yoga on blood pressure among school children. Asian J Pharm Clin Res 2018;11:399-403.

67. Kumar R, Pal R. India achieves WHO recommended doctor population ratio: a call for paradigm shift in public health discourse. J Family Med Prim Care 2018;7:841-4.

68. Sharkar M. Ayush dept under-utilises funds allocated during last three years; 2013 http://www.pharmabiz.com/NewsDetails.aspx?aid=77870and sid $=1$ [Last accessed on 10 Dec 2019]

69. Health Division Planning Commission Government of India. Report of the Steering Committee on AYUSH for 12th Five Year Plan; 2012-17. Available from: http://planningcommission.gov.in/aboutus/committee/strgrp 12/st_ayush0903.pdf [Last accessed on 10 Dec 2019]

70. Jain AK, Sharma BK. Developments in the field of ayurvedapast to present. Ayushdhara 2014;1:51-64. 